\title{
Impact of selected parameters on extraction of indium from LCD screens
}

\author{
Wpływ wybranych parametrów na proces ługowania indu \\ z ekranów LCD
}

\begin{abstract}
Due to the minute availability of indium and its crucial importance to the world economy, it is necessary to find alternative sources of this metal. As a large proportion of indium production is consumed for the purpose of LCD screen manufacturing, it seems reasonable to investigate their recycling leading to the recovery of this metal. The present work investigates the impact of time, temperature, and the concentration of sulfuric acid on the effectiveness of indium extraction from milled LCD panel glass scrap originating from portable computers manufactured between 2005 and 2012. The conclusion of our research defines the optimal conditions for extraction.
\end{abstract}

Keywords: indium, ITO, LCD panels, recycling

\section{Streszczenie}

Ze względu na niewielkie zasoby indu i jego kluczowe znaczenie dla gospodarki światowej konieczne jest poszukiwanie alternatywnych zasobów tego metalu. Ponieważ ind wykorzystywany jest głównie w produkcji ekranów w technologii LCD, racjonalny wydaje się ich recykling w kierunku odzysku tego pierwiastka. W niniejszej pracy zbadano wpływ czasu, temperatury oraz stężenia kwasu siarkowego na efektywność ługowania indu ze zmielonej frakcji szklanej paneli LCD pochodzących z komputerów przenośnych z lat 2005-2012. W wyniku badań określono optymalne warunki ługowania.

Słowa kluczowe: ind, ITO, panele LCD, recykling

\section{Introduction}

One of the most-important applications of indium in the world economy is the manufacture of ITO (Indium-Tin-Oxide). It is estimated that this process is responsible for more than $80 \%$ of the world's indium demand $[1,2]$. ITO is a mixture of two oxides: $\ln _{2} \mathrm{O}_{3}$, and $\mathrm{SnO}$, with mass proportions of $90 \%$ and $10 \%$ [3], respectively, whereas the content of indium is around $74 \%$. The most-wanted property of ITO is the connection of two particular

Michał Stępień Ph.D. Eng., Piotr Palimąka Ph.D. Eng., Andżelika Bukowska M.Sc. Eng.: AGH University of Science and Technology, Faculty of Non-Ferrous Metals, Krakow, Poland; mstepien@agh.edu.pl 
features - its low electric resistance (ca. $10^{-3} \Omega \cdot \mathrm{cm}$ ) [4] and good transmission of the visible spectrum of light (up to $75 \%$ ). Thus, it is not surprising that one of the most-popular applications of ITO is the creation of optically transparent and electrically conductive layers. These layers are commonly used, mainly in the construction of all types of LCD (Liquid Crystal Display) and TFT (Thin Film Transistor) flat screens [5] as well as photovoltaic panels $[4,6]$.

With technological development, we can observe a growing demand for devices that include LCD displays. These devices include portable computers, computer screens, television sets, and mobile phones/smartphones. Considering the scarce world indium resources and their very significant scattering in Earth's crust [7] (as well as the short service life of the aforementioned devices into account), used LCD screens can be utilized as an alternative source of indium [8].

Currently, the vast majority of the proposed indium recycling methods are based on acidic or alkaline extraction from initially processed LCD screens. This initial processing of an LCD panel usually includes its selective dismantling, crushing, and milling [9]. The removal of the organic phase from the adhesives that bind the respective glass elements of an LCD panel together may form another stage in the initial processing [10]. Research on acidic extraction most-frequently involves the use of hydrochloric acid [11, 12], nitric acid (V) $[11,13]$, sulfuric acid (VI) [14, 15], and mixtures of these acids (or with the addition of oxidizers) [14]. The present paper presents the impact of temperature, time, and concentration of sulfuric acid on the indium extraction process for used LCD panels.

\section{Experiment}

In our research, we utilized 12- to 17 -inch LCD screens from portable computers manufactured between 2005 and 2012. The investigated LCD panels were manually removed from the computer cases and divided into glass scrap, plastics, and PCB. After separation from the remaining elements, the glass scrap was cut into pieces sized ca. $5 \times 5 \mathrm{~cm}$ and then milled in a rod mill. In the case of this mode of LCD panel preparation, we achieved a powder with a grain size of less than $0.5 \mathrm{~mm}$. No method for the initial removal of organic scrap was utilized during the preparation of the LCD panels for extraction. Figure 1 presents the dismantled LCD panel with PCB connections and plastic scrap (Fig. 1a) and the already milled scrap prior to extraction (Fig. 1b).

The extraction process was conducted in a $2 \mathrm{M}$ solution of sulfuric acid with a solid to liquid phase ratio of $0.1 \mathrm{~g} / \mathrm{ml}$. During the process, the solution was intensively stirred with the use of a mechanical stirrer with a rotating speed of $300 \mathrm{rpm}$ and kept at a constant temperature. Due to the intensive agitation and high degree of fragmentation of the solid phase, the sample for determining the indium concentration was only taken at the end of each experiment. For our experiments, we utilized analytical-grade reagents and deionized water. 
a)

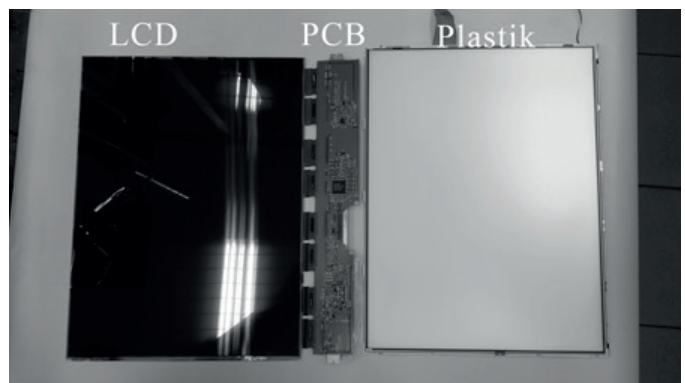

b)

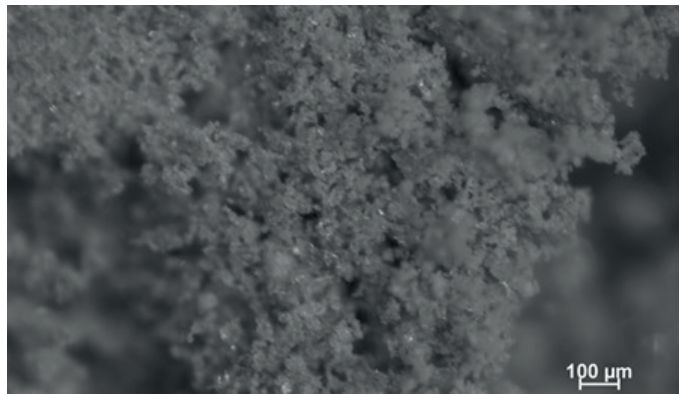

Fig. 1. Dismantle $L C D$ panel: a) product fractions of $L C D$ : $\angle C D$ panel, $P C B$, plastic, and PTFE-isolating layer; b) LCD panel after grinding

The determination of the elements in the extract was performed with the use of an MP-AES (Atomic Emission Spectroscope), Agilent 4200 (Australia). The determination of the main elements in the glass scrap was performed with the use of a WD-XRF (Wavelength Dispersive X-ray Fluorescence) of Rigaku Primini (Japan) apparatus.

\section{Results and discussion}

\subsection{Characteristics of chemical composition of used LCD panels}

Experiments on recycling selected types of consumer goods frequently encounter the problem of ascertaining the chemical composition of the processed material. This is the result of the differences in manufacturing processes among different manufacturers. For this reason, we obtained large differences while comparing different research results In the case of processing LCD panels, an additional difficulty comes from the presentation method for the content of the respective elements in the processed screens, as depending on the publication, this is quoted for the glass scrap alone or the screen as a whole together with the frame, electrical connections, and PCB. Table 1 presents the main components of the glass scrap of the LCD panels subject to our research. The analysis was performed with the use of the WD-XRF technique, assuming that all elements were in the form of oxides. 
Table 1. Main components of glass scrap of LCD panels, obtained by WD-XRF technique

\begin{tabular}{|c|c|c|c|c|c|c|c|c|}
\hline Composition & $\mathrm{SiO}_{2}$ & $\mathrm{Al}_{2} \mathrm{O}_{3}$ & $\mathrm{CaO}$ & $\mathrm{SrO}$ & $\mathrm{MgO}$ & $\mathrm{Fe}_{2} \mathrm{O}_{3}$ & $\mathrm{As}_{2} \mathrm{O}_{3}$ & $\mathrm{P}_{2} \mathrm{O}_{5}$ \\
\hline Mass [\%] & 61.95 & 17.98 & 8.13 & 6.05 & 2.72 & 1.75 & 0.48 & 0.44 \\
\hline
\end{tabular}

We also performed a trace analysis of In and $\mathrm{Sn}$ content through mineralization of the test sample in $4 \mathrm{M} \mathrm{H}_{2} \mathrm{SO}_{4}$ and a subsequent analysis of the resulting solution with the MP-AES. The determined contents of In and Sn were $300 \pm 25$ and $100 \pm 20$ ppm, respectively, which corresponds to results obtained in other works where the indium content of the processed panels was within a range of $50 \mathrm{ppm}$ to $600 \mathrm{ppm}[1,15,16]$.

\subsection{Impact of temperature and extraction time}

The impact of temperature and time on the efficiency of $\mathrm{In}, \mathrm{Sn}$, Fe, and Al extraction from milled $\mathrm{LCD}$ panels was investigated for $2 \mathrm{M} \mathrm{H}_{2} \mathrm{SO}_{4}$ in temperatures ranging from $30^{\circ} \mathrm{C}$ to $70^{\circ} \mathrm{C}$ and processing times from 15 minutes to 24 hours. The research results are presented in Figure 2.

What is particularly clear is the strong impact of temperature on the extraction efficiency of In and Fe during the first minutes of the process. In the research conditions for a temperature of $70^{\circ} \mathrm{C}$, the extraction degree of In exceeds $70 \%$ and $45 \%$ for Fe after only 15 minutes. Whereas at $30^{\circ} \mathrm{C}$, the extraction degree after 15 minutes was just $25 \%$ for In and $21 \%$ for Fe. The extraction process at $70^{\circ} \mathrm{C}$ allowed us to achieve a nearly $100 \%$ extraction rate for indium after 8 hours, with solution concentration levels in the range of $35 \mathrm{mg} / \mathrm{l}$, whereas the maximum indium gain at $30^{\circ} \mathrm{C}$ after 24 hours was in the range of just $80 \%$ and concentrations below $30 \mathrm{mg} / \mathrm{l}$. When we compare the aforementioned results with those obtained by Rocchetti et al. [1] (where an indium extraction rate of nearly $100 \%$ was achieved after 20 minutes of extraction at $80^{\circ} \mathrm{C}$ ), we see how significant the temperature is for the extraction process. The leaching efficiency is influenced far less by temperature for Fe and $\mathrm{Sn}$. After 24 hours, the leaching degree of Fe ranged between $50-55 \%$ (depending on the temperature used) and $55-65 \%$ in the case of $\mathrm{Sn}$. A strong influence of temperature on the final leaching degree is only visible in the case of aluminum, where at $30^{\circ} \mathrm{C}$, only $3 \%$ of this element was transferred to the solution; an increase of temperature to $70^{\circ} \mathrm{C}$ raises the final leaching efficiency to $12 \%$, and the concentration of $\mathrm{Al}^{3+}$ ions in the resulting solution exceeds $1 \mathrm{~g} / \mathrm{l}$. We can adopt 8 hours as the time required for achieving concentrations of $\mathrm{In}, \mathrm{Sn}$, and Fe ions for the whole investigated temperature range; a further extension of leaching times does not cause a significant increase in In concentrations and causes only a slight increase in $\mathrm{Al}^{3+}$ ion levels, which can be considered as undesirable in this solution. When indium extraction is considered, extraction at $70^{\circ} \mathrm{C}$ can be finished just after 2 hours, with leaching efficiency near $90 \%$ for that period of time. 
a)

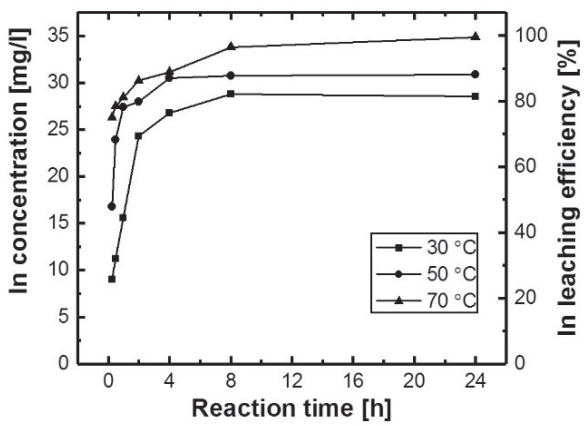

c)

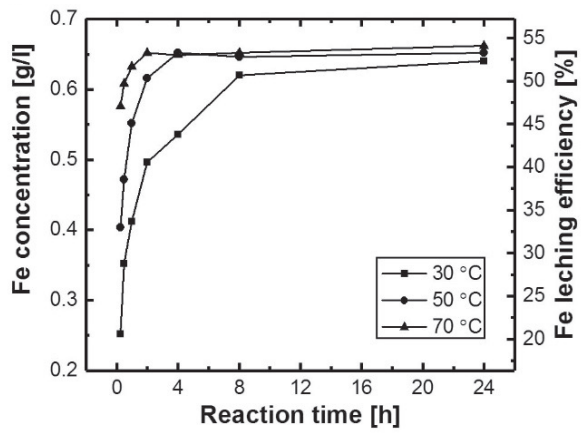

b)

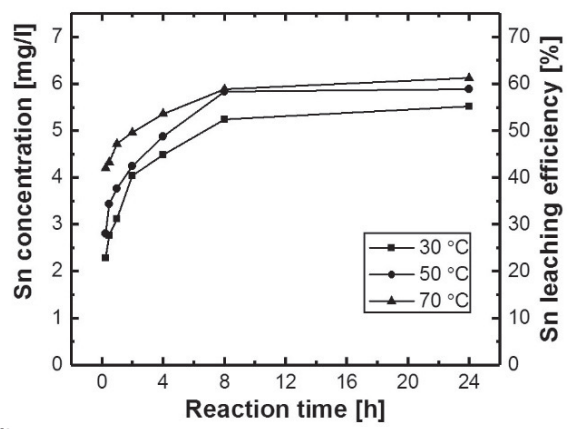

d)

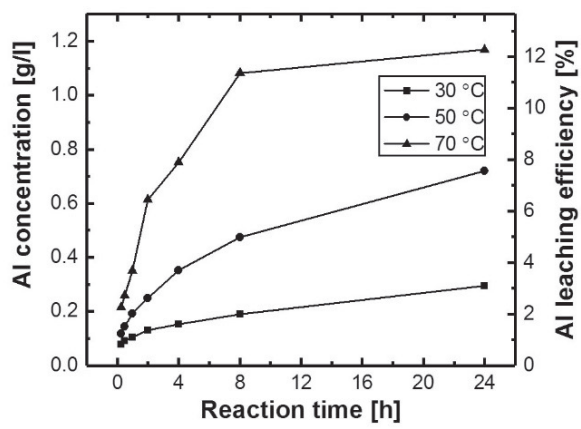

Fig. 2. Effect of temperature on: a) indium leaching; b) tin leaching; c) iron leaching; d) aluminum leaching

\subsection{Influence of acid concentration on extraction efficiency}

In order to investigate the influence of sulfuric acid concentration on $\mathrm{In}, \mathrm{Sn}, \mathrm{Fe}$, and $\mathrm{Al}$ extraction efficiency for milled LCD panels, we conducted an experiment with $\mathrm{H}_{2} \mathrm{SO}_{4}$ concentrations ranging from $0.01 \mathrm{M}$ to $2 \mathrm{M}$. The experiment was conducted at a constant temperature of $70^{\circ} \mathrm{C}$ for 2 hours, and the ratio of the solid to liquid phase was $0.1 \mathrm{~g} / \mathrm{ml}$. The change in In, $\mathrm{Sn}, \mathrm{Fe}$, and $\mathrm{Al}$ ion concentrations in the solutions as well as the leaching efficiency are presented in Figure 3. Extraction of indium under the aforementioned conditions ensures an extraction efficiency of greater than $80 \%$, provided that the $\mathrm{H}_{2} \mathrm{SO}_{4}$ concentration is equal to or higher than $0.5 \mathrm{M}$. For $\mathrm{H}_{2} \mathrm{SO}$ concentration ranges of $0.1 \mathrm{M}$ to $2.0 \mathrm{M}$, the extraction efficiency of Fe is rather constant. In the case of $\mathrm{Sn}$ and $\mathrm{Al}$, a significant decrease in extraction efficiency was observed for $\mathrm{H}_{2} \mathrm{SO}_{4}$ concentrations below $1.0 \mathrm{M}$. Therefore, it seems beneficial from the viewpoint of indium leaching to lower the $\mathrm{H}_{2} \mathrm{SO}_{4}$ concentration in the solution to approximately $0.5 \mathrm{M}$, as this lowers the $\mathrm{Sn}$ and $\mathrm{Al}$ ion content in the solution. 
a)

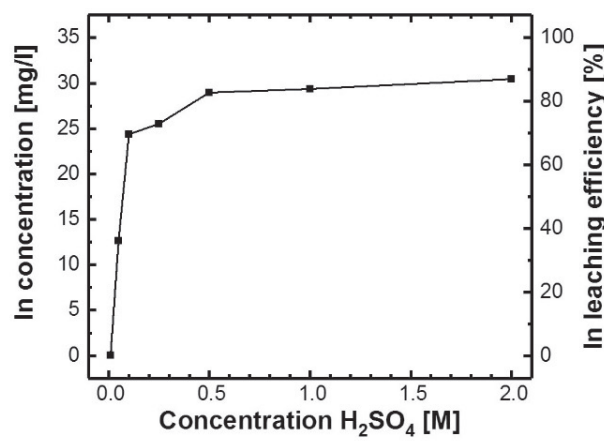

c)

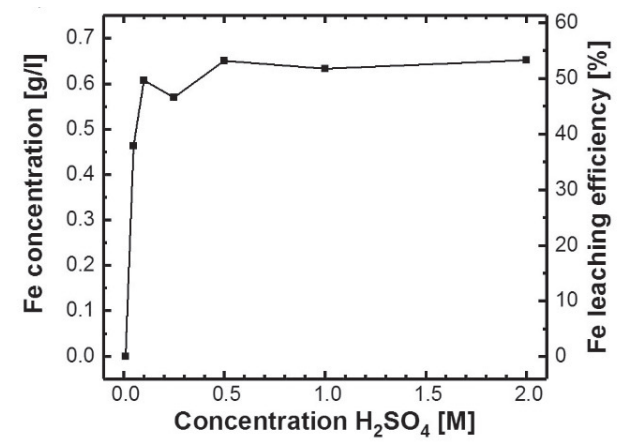

b)

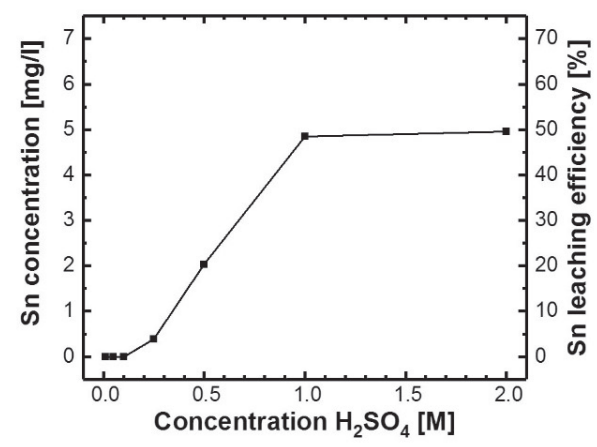

d)

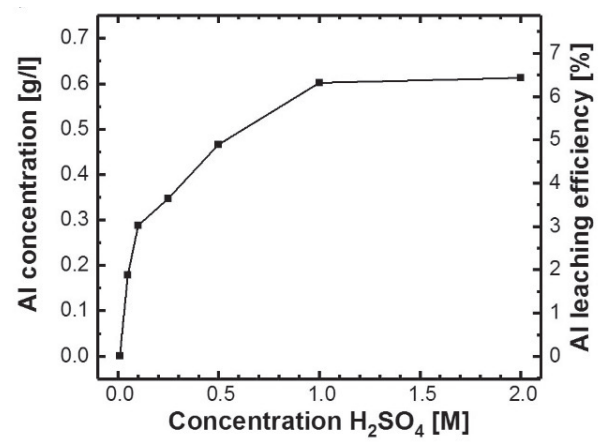

Fig. 3. Determination of concentration and leaching efficiency for In (a), $\mathrm{Sn}(b), \mathrm{Fe}(c)$, and $\mathrm{Al}$ (d) with respect to $\mathrm{H}_{2} \mathrm{SO}_{4}$ concentration

\section{Conclusions}

- The efficiency of indium leaching from milled LCD panels in a $2 \mathrm{M}$ solution of sulfuric acid at $70^{\circ} \mathrm{C}$ is near $100 \%$ after 8 hours of the process, and the indium concentration in the solution is approximately $35 \mathrm{mg} / \mathrm{l}$.

- Within the investigated temperature ranges, the concentrations of indium, iron, and tin are stabilized in the solution after 8 hours of leaching.

- Increases in extraction temperature beneficially influences the indium-leaching degree and the rate of the process. An increase in process temperature from $30^{\circ} \mathrm{C}$ to $70^{\circ} \mathrm{C}$ allows us to reach similar results in 2 hours instead of 24.

- Lowering the $\mathrm{H}_{2} \mathrm{SO}_{4}$ concentration to $0.5 \mathrm{M}$ does not cause a significant decrease in the efficiency of In extraction but significantly lowers the concentration of the undesirable $\mathrm{Sn}$ and $\mathrm{Al}$ ions in the solution.

- Extensions of extraction time to times in excess of 8 hours only causes an increase in $\mathrm{Al}^{3+}$ ion concentration in the solution for each of the investigated temperatures; this should be considered detrimental. 


\section{Acknowledgements}

The financial support from the Polish Ministry of Science and Higher Education Contract No. 15.11.180. 912 is gratefully acknowledged.

\section{References}

[1] Rocchetti L., Amato A., Fonti V., Ubaldini S., De Michelis I., Kopacek B., Vegliò F., Beolchini F.: Cross-current leaching of indium from end-of-life LCD panels. Waste Management, 42 (2015), 180-187

[2] Hasegawa H., Rahman M.M.I., Egawa Y., Sawai H., Begum Z.A., Maki T., Mizutani S.: Recovery of indium from end-of-life liquid-crystal display panels using aminopolycarboxylate chelants with the aid of mechanochemical treatment. Microchemical Journal, 106 (2013), 289-294

[3] Leung W.S., Chan Y.C., Lui S.M.: A study of degradation of indium tin oxide thin films on glass for display applications. Microelectronic Engineering, 101 (2013), 1-7

[4] Farhan M.S., Zalnezhad E., Bushroa A.R., Sarhan A.A.D.: Electrical and optical properties of indium-tin oxide (ITO) films by ion-assisted deposition (IAD) at room temperature. International Journal of Precision Engineering and Manufacturing, 14, 8 (2013), 1465-1469

[5] Chou W.L., Huang Y.H.: Electrochemical removal of indium ions from aqueous solution using iron electrodes. Journal of Hazardous Materials, 172, 1 (2009), 46-53

[6] Lee C.-H., Jeong M.-K., Kilicaslan M.F., Lee J.-H., Hong H.-S., Hong S.-J.: Recover of indium from used LCD panel by a time efficient and environmentally sound method assisted HEBM. Waste Management, 33, 3 (2013), 730-734

[7] Alfantazi A.M., Moskalyk R.R.: Processing of indium: A review. Materials Engineering, 16 (2003), 687-693

[8] Virolainen S., Ibana D., Paatero E.: Recovery of indium from indium tin oxide by solvent extraction. Hydrometallurgy, 107, 1-2 (2011), 56-61

[9] Ferella F., Belardi G., Marsilii A., De Michelis I., Vegliò F.: Separation and recovery of glass, plastic and indium from spent LCD panels. Waste Management, 60 (2017), 569-581

[10] Dodson J.R., Hunt A.J., Parker H.L., Yang Y., Clark J.H.: Elemental sustainability: Towards the total recovery of scarce metals. Chemical Engineering and Processing: Process Intensification, 51 (2012), 69-78

[11] Yang J., Retegan T., Ekberg C.: Indium recovery from discarded LCD panel glass by solvent extraction. Hydrometallurgy, 137 (2013), 68-77

[12] Swain B., Mishra C., Hong H.S., Cho S.-S.: Beneficiation and recovery of indium from liquid-crystal-display glass by hydrometallurgy. Waste Management, 57 (2016), 207-214

[13] Fontana D., Forte F., De Carolis R., Grosso M.: Materials recovery from waste liquid crystal displays: A foCus on indium. Waste Management, 45 (2015), 325-333

[14] Ruan J., Guo Y., Qiao Q.: Recovery of Indium from Scrap TFT-LCDs by Solvent Extraction. Procedia Environmental Sciences, 16 (2012), 545-551

[15] Zhang K., Wu Z., Wang W., Li B., Yhang Z., You T.: Recycling indium from waste LCDs: A review. Resources, Conservation and Recycling, 104 (2015), 276-290

[16] Krištofová P., Rudnik E., Miškufová A.: Hydrometallurgical Methods of Indium Recovery from Obsolete LCD and LED Panels. Metallurgy and Foundry Engineering, 42, 3 (2016), 157-170 